\title{
Re-Thinking the Very Concept of Peace
}

\author{
Arben Haxhiymeri \\ University "A. Xhuvani”, Elbasan, Albania
}

\section{Abstract}

The appreciation of Peace, the promotion of its values, and the efforts for its attainment as the only way to cope with horrifyingly destructive dimensions of the war we are facing with on a daily basis since so many long years all across the world urges nowadays to the extreme. This necessity appears to such an extent, and with such intensity, as to having been transformed more than ever in one of the most dominant catchphrases of political, social, intellectual and practical discourses of our violent times, a ubiquitous topic within universities, governments, civil societies and other non-governmental organizations and institutions. There are large pacifist movements which are facing off ever more actively against the war. There is also an ever more active engagement of many intellectuals and artists poised to face off against the hawkish and bellicose aesthetics we were facing with up to last two or three decades in most Western countries by a constructive bolstering and promotion of a peaceable and pacifistic aesthetics. By the 1970s the new discipline of peace studies, embracing the history and philosophy of peace, was well establish.1 Since 1980 there is even a university dedicated to Peace studies, the United Nations mandated "University for Peace", with its main campus in Costa Rica, which is launching its programs and establishing its centers around the world. About 30 years ago will faced and will be very active well known the CPP, Concerned Philosophers for Peace is the largest, most active organization of professional philosophers in North American involved in the analysis of the causes of violence and prospects for peace. And, many philosophers and thinkers are engaged in the international peace dialog and a large number of separated initiatives that have involving a significant number and pages of essays and conferences on philosophy of war and on the Philosophy of Peace, too.

Keywords: peace, war, pacifistic and anti-bellicistic theory, war philosophies

\section{Introduction}

\section{The peacemaking role of Philosophy in the actual world conflicts \\ Starting point}

Blessed are the peacemakers,

for they will be called sons of God.

Gospel according to Matthew, V, 9 .

In the last two or three decades various theories as to how world peace could be achieved have been proposed. However, we have no intention to embark in this paper upon a defense or assessment of any of them, neither to articulate any theory or ideology in regards. Rather than a mere partisan approach to this or to that pacifistic and anti-bellicistic theory or ideology whatsoever, for such a crucial question as peace the activation of a from-the-roots analytical approach is what we

\footnotetext{
1 Gittings J, (2015) Philosophy and Peace; Foreword to "The Question of Peace in Modern Political Thought", Koivukoski T. and Tabachnick D.E., Wilfred Laurier University Press 
necessarily need. And this is what we intend to do here. By examining analytically, from a philosophical viewpoint, the very concept of Peace, we aim to show the essential role Philosophy could play, and pricelessly constructive contribution it could give to what it can be considered as one of the greatest challenges faced by the societies of our time - that is, the prevailing of Peace and Reconciliation over War and Conflict.

Large-scale pacifistic and anti-bellicistic movements are nowadays a matter-of-fact, and, beyond any doubt, they are all positive. Nevertheless, what it is at stake in an issue as that of the peace is from a philosophical point of view of such a crucial importance as to not permitting us to limit ourselves to, and to be pleased with just highlighting the existence of pacifistic feelings and bemoaning attitudes against the war. However important these feelings and emotive responses may be, they are still not sufficient in themselves to make peace possible, nor to make it prevail over war and conflict. War and conflict often come into being and are moved on by forces essentially other than emotive ones.

Rather than emotional feelings and attitudes, the achievement of peace in a world that is tremendously devastated by wars and conflicts needs a multisided and multilevel radical change. And it is precisely at this very level that Philosophy can play its immense role and give its priceless constructive contribution, inasmuch as the human world rests upon, conforms to, and manifests the very conception we have of it. This premise applies both to its current and future states, to its actuality and potentiality. Our actual world is such, and not other, because such, and not other, is the very conception we have of it. There is absolutely no other alternative manner to change our world except by modifying and by transforming the conception we have of it. Rather than emotional feelings and bemoaning attitudes against the war, all we need today is first and foremost a from-the-roots change of the very conception of peace upon which most of actual large-scale pacifistic and antibellicistic movements are being based on.

Most of people do not love peace as such, for its being peace; most of people want peace because they have nowadays a sense of horror towards the horror of the war. It is this fear and horror of the war that constrains most of people to appreciate peace; the greater the sense of fear and horror of war, the greater the appreciation of peace. The result of all this is nothing but the depauperation of the concept of peace and of its nature on at least three genealogically and structurally interweaved levels: semantic, existential and ontological.

As for the first level, the concept of peace appears reduced to a mere negation of the war conceived as external physical violence only, leaving thus out other forms of violence, such as the spiritual, psychological, metaphysical, epistemological, symbolic, discursive, structural, cultural, anthropological, racial, political, economical, ecological, etc.

As for the second level, it is an inevitable consequence of the first level; once reduced to a mere negation of the war conceived as external physical violence only, peace becomes synonym of apathos, of inaction and lethargy, while war stands as synonym of pathos, of action and liveliness.

As far as the third level is concerned, it is an inevitable consequence of the second level; once reduced to apathos, to inaction and lethargy, peace appears a secondary, mediated reality, pertaining to the sphere of qualities and values, while the war appears a primary, initial reality, pertaining to the sphere of being; the first being thus artificial, suffering the everchanging equation of being and nonbeing, whilst the second is natural, enjoying the never-changing fullness of being.

This triple depauperation of the concept of peace is at the heart of Western culture since its very beginnings. The war, in the broadest and most literal sense of the word, forms the core of the very éthos of Homeric poems, which are beyond any doubt the fountain-head of the entire Western culture. The Greek term "pólemos", which signifies the "war", even as a hypostatized being, as "daímon", shares the very same etymology with "pólis", the "city-state", regarded as the very "éthos", the "dwelling place", the "living space" of the human beings ${ }^{1}$, expressing thus clearly enough the view that war is a pure

\footnotetext{
1 Homer, lliad, VI, 511; Odyssey, XIV, 411; Hesiodus, Theogony, 167 and 525; Herodotus, Historiae, I, 15 and 157; VII, 125; Plato, Laws, 865e etc.
} 
natural state, and, besides this, the political view that the "living space" of man (pólis, from which the term "politics" derives) is built on through war rather than through peace ${ }^{1}$. Besides these ontological and existential nuances, the war was the source of the aesthetic experience of the archaic Greek society. Sharing the same etymology of the verb "chairo", meaning "to be pleased", "to be satisfied", "to rejoice", and of the substantive "cháris", signifying the "grace", the "beauty", even as hypostatized being, as "daimon", the Greek term "chármi" does not refer to the "fighting" only, but first and foremost to the "pleasure received and experienced from the fighting"2. And the greatest pleasure received and experienced in and from fighting was what ancient Greeks used to name "kléos", a "commemoration", a "remembrance through song and poetry" the core of their cultural and moral éthos. ${ }^{3}$

This very idea was embraced and adopted from the successive generations and culture, to which belongs philosophy. For Heraclitus, the war and conflict was the very principle of all that it is, of the existence as a whole. "We must know that war (pólemos) is common to all and strife is justice, and that all things come into being through strife necessarily"4. "War is the father and king of all things, it shows some as gods, some as men; it makes some freemen and others slaves." ${ }^{5}$ For Sophocles the pure natural state of human being is that of "tò deinótaton", "the most open of the beings to suffer from and make use of the violence". This bellicistic cosmology and ontology are present - explicitly or implicitly - in most of modern philosophies; these "war philosophies", as Karl Popper defines them, can be gathered in three main groups: the biologicalvitalistic (Stirner, Darwin, Spencer, Nietzsche, Freud, Ortega y Gasset, Walzer, Dockrill etc.), the mechanistic-utilitarianistic (Machiavelli, Hobbes, Bacon, Locke, Grotius, Rousseau, Orinde etc.), and the dialectic-historicistic (Hegel, Marx, Lenin, Clauserwitz, Strauss etc.).

In spite of the differences, they all share the same conceptual view about the war. That is, the war is quite natural, profoundly biological, and practically unavoidable; that the war and violence represent the vitality through which the life overcomes itself, and by this, it generates its new possibilities.

Immanuel Kant reflection on the war and peace have extended over more than forty years, beginning from 1755 until to the first edition of Zum ewigen Frieden (Perpetual Peace), 1795, and Anthropologie in Pragmatischer Hinsicht ( known as Anthropology), at 1798, that was the final extended work entirely from Kant's own hand. ${ }^{6}$ We can see the evolution of ideas on the war and the peace through notable estimates of evils and benefits of wars, to the suggestion of a federation of nations and the perpetual peace. Kant thought that perpetual peace was an ideal to be approached but not completed. In Kant's language, it is an "ideal incapable of realization."7 It's interesting the interpretation of Hegel, in Philosophy of Right, on Kant's idea of perpetual peace as an ideal toward which mankind should approximate. ${ }^{8}$

Hegel had claimed more than once that antagonism is the very core of the dialectic self-evolution of the Objective Spirit or Objective Mind, and more, according to what make evident Karl Popper, Hegel thought that "war is not a common and abundant evil but a rare and precious good"s.

More, it will be no right to charge the Marks' paradigm as the first "war philosophy", or "class struggle philosophy" ; that's enough to come here a piece of the Marx' letter (1852) to J. Weydemeyer, in New York:

\footnotetext{
${ }^{1}$ Haxhiymeri A, (2014), "A History of Western Ethics"vol. I (Një histori e Etikës perëndimore" Vëll.I); Edited by Ideart, Tiranë.

2 Homer, Iliad, IV, 222; VIII, 252; XII, 203, 393; XIII, 82 etc.

${ }^{3}$ Bailly, A. (2012). Le grand dictionnaire étymologique du grec ancien, Paris, Hachette.

${ }^{4}$ Heraclitus, (1960) Peri physeos, in: Die Fragmente der Vorsokratiker (Diels, H./Kranz, W.) v. I, Weidmannsche Verlagsbuchhandlung,

Berlin, B80.

5 Ibidem, B53.

${ }^{6}$ Armstrong A.C. (1931) Kant's Philosophy of Peace and War; The Journal of Philosophy. Vol.28, No.8

${ }^{7}$ Kant I, (1991) Metaphysics of Morals; Sec. 61, Kant's Political Writings: Cambridge University Press, p.171.

${ }^{8}$ Fiala A. (2006) The Vanity of Temporal Things: Hegel and the Ethics of War; Studies in History of Ethics, Peer Reviewed elect.jurnal, California State University, Fresco, USA

${ }_{9}$ Popper K, (1971) The Open Society and Its Enemies ; Princeton, NJ: Princeton University Press, , II: 71
} 
"...no credit is due to me for discovering the existence of classes in modern society or the struggle between them. Long before me bourgeois historians had described the historical development of this class struggle and bourgeois economists, the economic economy of the classes"

Whereas, in Nietzsche's words, "the war is a condition to the life's generation". After few years Bertrand Russell have been tried to classified the wars in the his articles Ethics of the War $(1915)^{1}$, and so-called the class struggles would be the Wars of Principles; we can make the difference between the class struggles and the civil war, or to the violent revolution.

Peace must be understood some dimensions: personal, social, national, international and global, etc. So, we can remember the ancient cultures and meanings of peace, such as goddess of peace Irene in the Greek tradition which leads to material well-being, Salam that expresses a wish for peace interpersonal dimension of relations, etc. ${ }^{2}$

What we need nowadays is precisely the from-the-roots change of the very conception of peace and its respective nature. And this can not be but a challenging task of Philosophy, which is called on today, more than ever, to embark on that very path that Heidegger defined paradigmatically as a "metanoic evolution". More than to fostering just pacifistic and antibellicistic feelings and attitudes, the actual task of Philosophy is to deracinate what it has itself planted, the triple supremacy of the war over the peace. It is its duty and mission towards the very future of the humanity to eliminate the semantic dependency of the concept of peace on that of the war; it is its duty and mission towards the very future of the humanity to eliminate the reduction of the concept of peace to a mere negation of the war conceived as an external physical violence; it is its duty and mission towards the very future of the humanity to eliminate even the reduction of the war to a mere external physical violence only; it is its duty and mission towards the very future of the humanity to work on for the conception of peace as a vital state, as it did for the conception of war. Finally, it is its duty and mission towards the very future of the humanity to work on for the conception and the development of a new anthropology - an anthropology that could pave the way for a possible semantic and existential supremacy of peace over the war, as far as the war will continue to exist as a reality in its own, same as the peace, and in such a case, when we choose one of two alternatives, we will choose peace for the peace sake, or war for the war sake, without any "because of" in-between. And to do this, Philosophy must work on for the conception of human being as personal, that is, as an opened, co-existential, relational and dialogic being. And to continue with conception of reason and wisdom, so on. It's a very crucial role to revision the idea of reason, to revitalize the notion of wisdom and philosophy. As we can select by professor Jenny Teichman:

"The inimical "appearance of reason," which permeates contemporary philosophy, is the result of Western man abandoning his search for wisdom, distorting his "philosophical vocabulary," and "pervert(ing) the meaning of the noetic symbols."'3

Certainly it is an extremely difficult task, but not impossible. And we have no doubt that Philosophy can achieve it successfully. For our human world rests upon, conforms to, and manifests the very conception we have of it. And this premise applies both to its current and future states, to its actuality and potentiality. Our world will not be such as it is, but other, because other, and not such as it is, will be the very conception we will have of it.

\section{References}

[1] Gittings J, (2015) Philosophy and Peace; Foreword to "The Question of Peace in Modern Political Thought", Koivukoski T. and Tabachnick D.E., Wilfred Laurier University Press

[2] Homer, Iliad, VI, 511; Odyssey, XIV, 411; Hesiodus, Theogony, 167 and 525; Herodotus, Historiae, I, 15 and 157; VII, 125; Plato, Laws, 865e etc.

\footnotetext{
${ }_{1}^{1}$ Russell B, (2015) The Ethics of the War, International Journal of Ethics, vol.25, No. 2, pp127-142. (University of Chicago Press).

2 Rai Chhaya, (2011) Moral Philosophy of Global Peace; Madhya Pradesh, India,.

${ }^{3}$ Teichman J, (2006) The Philosophy of War \& Peace, Imprint Academic, UK/Sharlottesville,
} 
[3] Homer, Iliad, IV, 222; VIII, 252; XII, 203, 393; XIII, 82 etc.

[4] Haxhiymeri A, (2014), "A History of Western Ethics"vol. I (Një histori e Etikës perëndimore" Vëll.l); Edited by Ideart, Tiranë, Albania.

[5] Bailly, A. (2012). Le grand dictionnaire étymologique du grec ancien, Paris, Hachette.

[6] Heraclitus, (1960) Perì physeos, in: Die Fragmente der Vorsokratiker (Diels, H./Kranz, W.) v. I, Weidmannsche Verlagsbuchhandlung, Berlin, B53, B80.

[7] Armstrong A.C. (1931) Kant's Philosophy of Peace and War; The Journal of Philosophy. Vol.28, No.8

[8] Kant I, (1991) Metaphysics of Morals; Sec. 61, Kant's Political Writings: Cambridge University Press, p.171.

[9] Fiala A. (2006) The Vanity of Temporal Things: Hegel and the Ethics of War; Studies in History of Ethics, Peer Reviewed elect.jurnal, California State University, Fresco, USA

[10] Popper K, (1971) The Open Society and Its Enemies ; Princeton, NJ: Princeton University Press, , Il: 71

[11] Marx K, (2000) The Letter of Marx to J. Weydemeyer, (1852), Marx/Engels, Internet Archive (marxists.org)

[12] Russell B, (2015) The Ethics of the War, International Journal of Ethics, vol.25, No. 2, pp127-142. (University of Chicago Press).

[13] Rai Chhaya, (2011) Moral Philosophy of Global Peace; Madhya Pradesh, India.

[14] Teichman J, (2006) The Philosophy of War \& Peace, Imprint Academic, UK/Sharlottesville 